\title{
VIEWS OF TAX AGENTS ON THE MALAYSIAN TAX SYSTEM AND COMPLIANCE BURDEN: QUALITATIVE ANALYSIS
}

Noor Sharoja Sapiei, ${ }^{1}$ Mazni Abdullah, Kamisah Ismail \& Suria Zainuddin

\begin{abstract}
This study focuses on the compliance burden of Malaysian corporations from the perspective of tax agents. Two main areas are investigated, namely, suggestions for reducing the tax compliance burden of companies and improving the Malaysian tax system. Based on the qualitative analysis, the following measures are laid out from the perspective of lowering the compliance burden: (i) improve the accountability and transparency in tax administration matters, (ii) simplification of tax incentive requirements, and (iii) convergence of tax law with accounting standards in order to reduce discrepancy and tax adjustments. This study benefits the tax literature and the Malaysian tax practice by providing reliable qualitative research findings for establishing guidelines and policies pertaining to the compliance burden of corporate taxpayers.
\end{abstract}

Keywords: Tax Compliance Burden, Qualitative Analysis, Tax Agents

\section{Introduction}

Tax compliance costs are costs incurred by taxpayers as a result of their obligation to the relevant tax laws in force in a country. Ariff and Pope (2002) categorised the taxation compliance costs into economic and non-economic costs. They classified economic costs as monetary and time costs (Figure 1), and non-economic costs as costs of stress and anxiety caused by tax compliance (psychological costs). According to the authors, economic costs can be estimated, while non-economic costs are difficult to quantify. They also identified miscellaneous costs under

\footnotetext{
Corresponding author: Dr Noor Sharoja Sapiei is a Senior Lecturer at the Faculty of Business \& Accountancy, University of Malaya, email: noorsharoja @um.edu.my. All the co-authors are Senior Lecturer at Faculty of Business \& Accountancy, University of Malaya.
} 
internal economic costs, which, basically, constitute other costs incurred in complying with the tax laws (incidental costs).

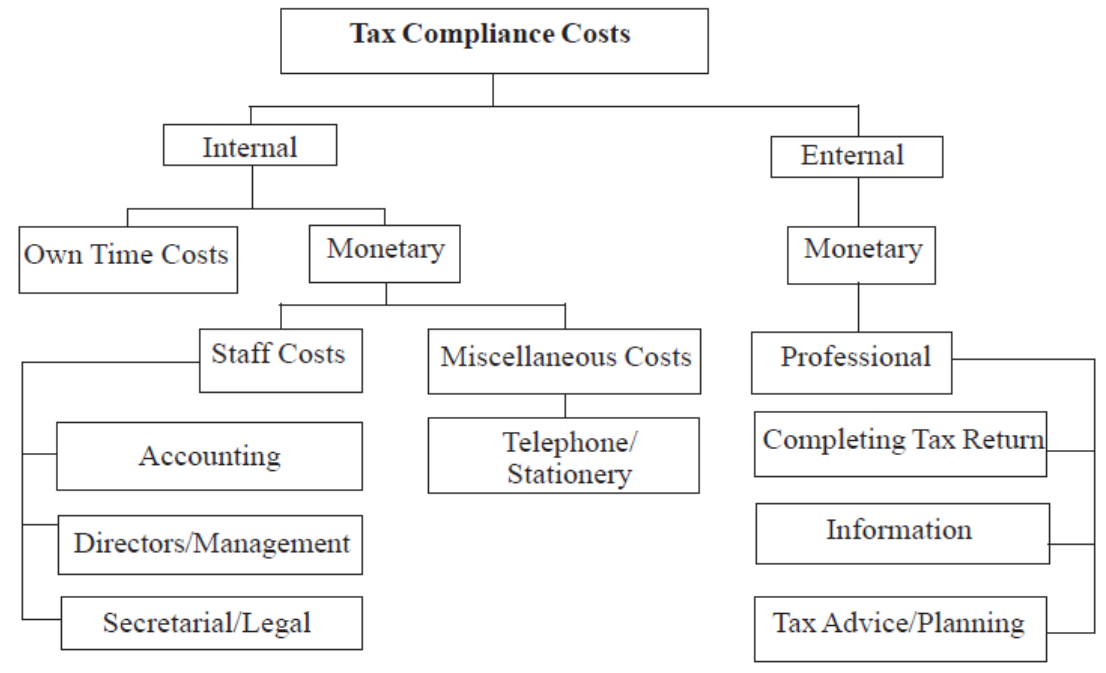

Source: Arif and Pope (2002)

Figure 1 Economic Compliance Costs of Business Taxation

Based on the existing literature, the theoretical components of tax compliance costs consist of the following: (i) internal costs - value of time spent by company staff on tax matters; (ii) external costs - fees paid to tax agents; (iii) incidental costs - other miscellaneous tax costs, which may include travel, stationery, computer, telephone and court litigation costs; and (iv) psychological costs - negative experiences of taxpayers in complying with tax legislation.

This paper presents a qualitative analysis of the compliance burden incurred by the corporate taxpayers in complying with the Malaysian tax system from the perspective of external tax professionals. Specifically, the research objective of this study is stated as follows: "To explore the views of tax agents on the Malaysian tax system and the tax compliance costs incurred by Malaysian corporate taxpayers under the self-assessment system (SAS)". The rest of this paper is organized as follows. A survey of related literature is provided in Section 2. Section 3 describes the research method employed in this paper. The results of the qualitative analysis concerning reducing compliance costs burden and improving the overall Malaysian tax system are reported in Section 4. Finally, Section 5 concludes this paper. 


\section{Literature Review}

The theoretical recognition of tax compliance costs was identified in the early eighteenth-century by Adam Smith (Evans, 2003) in his famous work, The Wealth of Nations. The book, which was published in 1776, suggested a set of principles that are also known as the canons of taxation for a good tax system. The author proposed that a good tax system is one that satisfies four principles: (i) equity, (ii) certainty, (iii) convenience, and (iv) efficiency.

\section{(i) Canon of Equity}

This principle states that a tax system should be fair among taxpayers and taxes should be levied in accordance with the ability to pay. A good tax should be proportional to income so that the burden of supporting a government is in accordance with the benefits received from the government. In the words of Smith [1776 (1999 ed.), p. 416]:

\section{"The subjects of every state ought to contribute towards the support of the government, as nearly as possible, in proportion to their respective abilities; that is, in proportion to the revenue which they respectively enjoy under the protection of the state."}

\section{(ii) Canon of Certainty}

According to this principle, a good tax system should ensure that taxpayers are clear about their tax compliance obligations, such as the amount of tax that is payable, the method of payment and the deadline for payment. Smith [1776 (1999 ed.), p. 416], in this connection, remarked:

"The tax which each individual is bound to pay, ought to be certain, and not arbitrary. The time of payment, the manner of payment, the quantity to be paid, ought all to be clear and plain to the contributor, and to every other person."

\section{(iii) Canon of Convenience}

The principle of convenience implies that the time and mode of payment of a tax should be the most conducive to taxpayers. People would more conveniently pay tax if it is being deducted at the source rather than paying a large amount of tax annually (Lymer \& Oats, 2009). In Malaysia, the scheduled monthly tax deduction and e-filing are among the examples of convenience in terms of timing and manner of payment. In the words of Smith [1776 (1999 ed.), pp. 416-417]:

"Every tax ought to be levied at the time, or in the manner, in which it is most likely to be convenient for the contributor to pay it." 
(iv) Canon of Efficiency

The principle of efficiency (also known as economy or simplicity) is achieved when the cost of administering the tax system is not excessive. The costs of tax collection should be the lowest possible so that a large fraction of what is acquired from the taxpayers will be available for public spending (Lymer \& Oats, 2009). Smith [1776 (1999 ed.), p. 417] recognised these characteristics when he wrote:

"Every tax ought to be so contrived as both to take out and to keep out of the pockets of the people as little as possible, over and above what it brings into the public treasury of the state."

In the context of these principles, the lack of certainty in tax legislation and the inconvenience prevalent in a tax system would expose taxpayers to unnecessary predicament and oppression, thereby increasing their compliance costs burden (Yesegat, 2009). Smith [1776 (1999 ed.), p. 417] acknowledged this problem when he wrote:

"...forfeitures and other penalties which those unfortunate individuals incur who attempt unsuccessfully to evade the tax, it may frequently ruin them, and thereby put an end to the benefit which the community might have received from the employment of their capitals."

In addition, a psychological burden in terms of stress and anxiety may be imposed on taxpayers, as legislation requires them to carry out complex obligations under the threat of legal penalty (Sandford, Godwin, Hardwick \& Butterworth, 1981). Smith [1776 (1999 ed.), p. 418] in this connection, remarked:

" ..... subjecting the people to the frequent visits and the odious examination of the tax-gatherers, it may expose them to much unnecessary trouble, vexation, and oppression; and though vexation is not, strictly speaking, expense, it is certainly equivalent to the expense at which every man would be willing to redeem himself from it".

Due to changes in the economic activities and functions of the government since the era of Adam Smith, various additional principles of taxation have been introduced by the modern economist. Musgrave, Musgrave and Bird (1987, pp. 207-208) summarised the major important principles of a good tax system:

a. The distribution of the tax burden should be equitable. Everyone should be made to pay his or her 'fair share'.

b. Taxes should be chosen so as to minimize interference with economic decisions in otherwise efficient markets. Such interferences impose 'excess burdens' which should be minimized. 
c. Where tax policy is used to achieve other objectives, such as to grant investment incentives, this should be done so as to minimize interference with the equity of the system.

d. The tax structure should facilitate the use of fiscal policy for stabilization and growth objectives.

e. The tax system should permit fair and non-arbitrary administration and it should be understandable to the taxpayer.

f. Administration and compliance costs should be as low as is compatible with the other objectives.

These updated and extended canons of good tax practice emphasise more on the impact of tax compliance costs on the taxpayers caused by the interferences and arbitrariness in the tax system (Musgrave et al., 1987). The following paragraphs present a review of the empirical studies of the tax compliance burden of taxpayers.

Studies concerning the estimation of tax compliance costs were conducted mainly in developed countries, especially in the UK (see Sandford 1973; Godwin \& Sandford, 1983; Sandford et al., 1981; Sandford, Godwin \& Hardwick, 1989; Sandford, 1990, 1995a and 1995b); the US (Arthur D. Little Inc., 1988; Slemrod \& Blumenthal, 1996; Slemrod \& Sorum, 1984; Slemrod \& Venkatesh, 2002); and Australia (Evans, Ritchie, Tran-Nam \& Walpole, 1996, 1997; Pope, 1992, 1993; Pope, Fayle \& Chen, 1991). To date, at least one study has been conducted in each country in the Organisation for Economic Co-operation and Development (OECD) countries, for example, Erard (1997) in Canada, Sandford and Hasseldine (1992) in New Zealand, and Chan, Cheung, Ariff and Loh (1999) in Hong Kong.

Studies relating to corporate taxpayers in the advanced economies make many important contributions. Apart from establishing many of the measurements and conceptual issues in estimating tax compliance costs, two major aspects of compliance costs have emerged from these studies:

i. The compliance costs of changes in the tax system tend to be high and the costs increase with the complexity in the tax system.

ii. Compliance costs comprise a significant share of tax related costs and are high, either measured in absolute money terms, as a percentage of income tax revenue or as a percentage of the GDP.

Studies in the developing countries are not well established due to the lack of experts in the area of tax compliance costs, which is exacerbated by a lack of co-operation from the tax authorities (Klun, 2004). Other factors for minimal research listed by Ott and Bajo (2000) include no taxpayer associations and civil initiatives, as well as tax experts being normally overloaded by more pressing issues. Limited studies in the emerging economies include Klun (2001) in 
Slovenia, Bertolucci (2002) in Brazil, Chattopadhyay and Das Gupta (2002) in India, and Blazic (2004) in Croatia.

Tax studies in Malaysia are very limited, especially with respect to the tax compliance costs estimations. A review of the literature only revealed three published studies on corporate income tax (CIT) compliance costs in Malaysia. These were by Loh et al. (1997), Hanefah, Ariff and Kasipillai (2001), and AbdulJabbar (2009). The findings from these studies concluded that the compliance costs are relatively low compared to countries with advanced economies. Moreover, it is only in recent times that studies on tax compliance costs have become a subject of interest for investigation in developing economies.

The World Bank administers worldwide comparisons on an annual basis concerning the cost of doing business that comprise the cost of remitting and collecting taxes. ${ }^{2}$ The report addresses the taxes and mandatory contributions that companies must remit or withhold in a tax year, together with the measures of the administrative burden in complying with the tax regulations. In the World Bank Doing Business 2008 Report on the Paying Taxes indicator, Malaysia ranks 56th among the 178 countries. Based on this information, a study into the compliance costs burden of corporate taxpayers, especially with regards to qualitative analysis, is timely and necessary.

\section{Research Method}

The sample for this study was drawn from the list of tax agents from the website of the IRB. As this study requires responses on tax fees incurred by corporations, tax agents who are attached to or have been attached to accounting firms with companies as their tax clients, were deliberately selected. By utilising purposive sampling, a total of 185 tax agents were identified for this study.

The questionnaire for this study adopted items, which were developed by existing studies (see Abdul-Jabbar, 2009; Green, 1994; Sandford et al., 1989; Slemrod \& Venkatesh, 2002). The questions elicited the views and suggestions of the tax agents concerning the tax compliance burden of companies and the Malaysian income tax system.

Table 1 Questionnaire Items

\begin{tabular}{l|l}
\hline Items & Question \\
\hline $\begin{array}{l}\text { Reducing the tax } \\
\text { compliance burden }\end{array}$ & $\begin{array}{l}\text { 'Do you have any specific suggestion for reducing the tax } \\
\text { preparation work and documentation in respect of corporate income } \\
\text { tax for companies?' }\end{array}$ \\
$\begin{array}{l}\text { Improving the } \\
\text { 'In the light of your experience, do you think the company income } \\
\text { tax system could be improved?' }\end{array}$ \\
\hline
\end{tabular}

2 The research study and corresponding data are accessible at http://www.doingbusiness.org. 
Data collection for this study utilised a researcher-administered questionnaire survey method. ${ }^{3}$ By utilising this method, questionnaires can be personally distributed, which provides the opportunity for researchers to verbally emphasise the importance of the study and appreciation for the individual's collaboration. When required, the researchers may cautiously provide some clarifications and/ or examples with respect to certain difficult, sensitive or important questions. ${ }^{4}$

The responses of the tax agents relating to information about companies were sought as most corporations may not have an in-house tax compliance department but instead outsource all their tax activities. Therefore, valuable information can be obtained from a survey of these professionals who handle the tax affairs of companies. It was deemed acceptable as these groups appear to possess significant work experience and the appropriate professional qualifications, which would enable them to provide reasonable information for the purposes of this study.

\section{Research Analysis}

The responses to the open-ended questions were analysed using content analysis. Content analysis is a systematic, reliable and replicable technique for condensing many words of text into fewer content categories based on explicit rules of coding (Steve, 2001; Weber, 1990).

\subsection{Response Rate and Sample Demographics}

Forty-nine (49) respondents completed the researcher-administered survey, furnishing a response rate of 24.5 per cent. All completed questionnaires were examined for accuracy of data and missing values prior to data entry. Follow-up calls and e-mails were made to address missing items and to clarify matters of possible incorrect responses. Table 2 provides the demographic profile of the tax agents involved in this study.

There were almost an equal percentage of respondents practicing in the bigfour accounting firms (49 per cent) and non-big four accounting or tax firms (51 per cent). A large majority of respondents in these firms were partners (63.3 per cent), followed by managers (20.4 per cent) and senior/junior staff (16.3 per cent).

Nearly all of the respondents were members of at least one of the accounting or tax professional bodies, either locally or internationally. More than 67 per cent of the tax agents surveyed were members of the Malaysian Institute of Accountants (MIA), and almost 45 per cent were registered with the Chartered Tax Institute of Malaysia (CTIM). Other professional bodies included the Association of Chartered Certified Accountants (ACCA), Institute of Chartered Accountants in England and Wales (ICAEW) and CPA Australia (42.9 per cent).

\footnotetext{
The questionnaires used have been formally approved by the Human Ethics Committee at the Monash University.

4 According to Robson (2002), this method of data collection can facilitate a good quality of data, as, if needed, the researcher has the advantage of clarifying survey questions with the respondents.
} 
Table 2 Demographic Profile of External Tax Agents

\begin{tabular}{l|ccc}
\hline Demographic Profile & $\begin{array}{c}\text { Number of } \\
\text { Respondents }\end{array}$ & Percentage & $\begin{array}{c}\text { Cumulative } \\
\text { Percentage }\end{array}$ \\
\hline Practice: & 24 & 49.0 & 49.0 \\
$\begin{array}{l}\text { Big-four Accounting Firm } \\
\text { Non big-four firm/Tax Firm }\end{array}$ & 25 & 51.0 & 100.0 \\
Position: & 31 & 63.3 & 63.3 \\
Partner & 10 & 20.4 & 83.7 \\
Manager & 8 & 16.3 & 100.0 \\
Senior/Junior & & & \\
Membership: a & 22 & 67.4 & 67.4 \\
MIA & 21 & 44.9 & 112.3 \\
CTIM & & 42.9 & 115.2 \\
Others & 7 & 14.3 & 14.3 \\
Tax Experience: & 17 & 34.7 & 49.0 \\
Less than 10 years & 25 & 51.0 & 100.0 \\
10 to 20 years & & & \\
More than 20 years & &
\end{tabular}

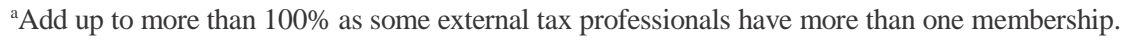

In terms of tax experience, 51 per cent have more than 20 years of professional experience, 34.7 per cent have experience of between five to 10 years and only 14.3 per cent have less than 10 years of professional exposure. Thus, it can be concluded that the survey data were obtained from tax agents who held appropriate positions, and had adequate knowledge and experience to handle the tax matters of their respective corporate tax clients.

\subsection{Qualitative analysis}

The tax agents were given the chance to recommend measures to reduce the compliance costs burden of their tax clients, and improve the overall CIT system.

\subsubsection{Reducing Compliance Costs Burden}

Concerning the suggestions to reduce the compliance costs burden, 43 tax agents provided their feedback. In an effort to mitigate the burden of compliance costs, the main suggestions pertained to the simplification of tax legislation and reporting requirements. The following comment from a respondent illustrates this point:

'The tax authorities should simplify the tax legislation; streamline and harmonise execution and practices and issue guidelines speedily (on a timely basis) before reporting deadlines.' 
Around one third of the respondents suggested tax simplifications, and further identified the IRB requirement for tax estimations as a major contributor to the tax compliance burden of taxpayers. Hence, the tax agents suggested a few measures, such as to reduce:

a. frequency of tax estimate revision;

b. penalty for underestimation of tax instalment as it is difficult to get an accurate estimate, and;

c. terminate the compound for the late submission of CP204 (tax estimation form).

The respondents who found tax estimation to be a problem also mentioned the complexity arising from frequent legislative changes. A wide variety of suggestions in relation to tax simplification were given, which included:

a. 'Taxpayers to provide information for the first time and only update when there are subsequent changes.'

b. 'Please do not give general order as they may mislead tax agent and public.'

c. 'IRB should be more transparent when passing new circulars or rules regarding the ITA and need to give clearer explanation and instruction.'

d. 'IRB to provide software at reasonable prices to tax agents.'

e. 'Dormant company with no big activity may be just reduced to four lines instead of the present few pages of submission.'

f. 'To allow certain tax submission mechanism without audited report being finalised such as delayed lodgement'

Secondly, the survey respondents comprising tax agents suggested that companies should invest more in technical training for the development of their internal staff. They had noticed that some of their tax clients were quite ignorant about the tax laws and even about basic tax requirements. They also felt that it would be useful for companies to be aware of proper documentation in order to ensure a timely and accurate set of accounts for tax compilation. Moreover, higher compliance with documentation by the taxpayers would reduce the tax preparation work, and clients should also consider using effective software that can integrate accounting and tax data. The following two comments from the tax agents summarise these points:

'Companies should maintain separate files for tax purposes. Ensuring the internal/external documentation in relation to corporate tax matters is in place and properly documented to avoid the risk of penalty and additional taxes during tax audit conducted by the IRB, and for ease of preparation of the tax computation. Companies must ensure 
that they communicate the importance of tax and its documentation to the whole office and enforce every department, i.e. sales department, to do its part'

'The vast majority of bookkeepers in this country possess a very low level of skills. Unless this problem is adequately addressed on a national scale with proper allocation of expenses, there will be a perpetual major problem. This, in turn, is translated into a nightmare for conscientious and ethical tax agents given the statutory duties and responsibilities imposed on them.'

Thirdly, the point was made concerning the need for convergence of the tax regulations with the accounting standards and practices. This could be achieved through the acceptance of audit documentation, as part of tax evidence, and/or by having the same treatment for accounting standards and tax laws. The main examples of conflict between the accounting and tax treatments, which imposed compliance costs, included the differences in accounting requirements concerning the provisions for depreciation and tax requirements on the capital allowances computation for the same corporate fixed assets.

Fourthly, issues regarding tax incentives provided under the ITA were mentioned by several respondents. They asserted that rules in relation to tax incentives should be straightforward through the abolishment of certain incentives or reduction of the restrictions for qualifying for the incentives. The following comments from a respondent illustrate these points:

Simplify the way to calculate the tax of companies with incentive. Instead of different rates of incentive, give the same rate for all, e.g. for incentives under ITA, allow all 100\% exemptions. At present, the areas open for disputes concern reinvestment allowance (RA) as IRB adopts a very narrow and limited interpretation of the ITA and seems to be anti-business reinvestment. Even if $R A$ is eventually disallowed, there shouldn't be any penalty imposed.'

Fifthly, there was also considerable anxiety about the IRB's audit and investigation process. The tax agents solicited a more lenient treatment of the tax audits of their clients, especially for immaterial items. In addition, there were certain items, such as bad debts, which the IRB would normally pick on during a field audit, and make it very difficult for taxpayers to claim a deduction. The following comment from a respondent illustrates these points:

'The IRB should adopt a more liberal approach in the tax audit and investigation cases instead of always interpreting the law to their benefit. Good tax should be paid but this does not mean that the IRB 
can abuse their authority and threaten the client to open the files of their directors if they don't give in to their request.'

Other issues that received numerous suggestions included continuity of tax rules, clearer and more concise tax legislation, greater use of e-filing, staggered filing timeline for a group of companies or group filing of tax returns, improvement of the appeal process, and free and easy to use record keeping programs for taxpayers to use.

\subsubsection{Improving the Overall Tax System}

Next, based on their knowledge and experience, the survey respondents comprising tax agents were also requested to respond to a question regarding improvements to the Malaysian income tax system. Responses from this openended question generated a rich variety of suggestions regarding improvements to the Malaysian corporate income tax system.

Generally, the respondents believed that the tax authorities should follow the more established tax system from countries with advanced economies. The following comments from the respondents illustrate this point:

'Take a look at other more developed countries concerning how they approach the company income tax system. There's a lot to learn from there in terms of efficiency in preparing tax returns and the way the IRB handles tax issues.'

Make tax administration simple, such as reduce corporate tax rate while removing other complicated incentives, just like developed countries.'

More specifically, regarding the suggestion to improve the Malaysian income tax system, most of the responses pertained to the clarity of tax legislation and transparency of tax laws. Apart from reducing ambiguous terminology in the tax legislation, the tax agents called for more effective and logical public rulings, a better advanced rulings system, simpler tax returns, and a regular dialogue session between the IRB and tax practitioners. They also pointed out the lack of accountability and transparency in tax administration matters.

In respect of the notion to improve the transparency of tax laws and their implementation, the tax agents were desirous for the IRB to issue fairer and more equitable legislation, together with greater transparency in the interpretation of the legislation. Two examples provided concerned the issuance of public rulings, which should not be biased to the views of the IRB, and the adoption of case law decisions, even though they were not in favour of the IRB. In addition, the respondents suggested that the policy and technical documents should be made available to the tax agents. 
Another valuable suggestion by the tax agents was for a reduction in the discretionary power of the Director General of the IRB. In their opinion, the issues concerning the ill effects of the director-general's sole administrative discretionary power have been criticised by many over the years, without any improvement. This directed us to another point concerning the competency of the tax officers. Some of the major dissatisfaction regarding the current Malaysian tax system related to the unhelpful attitude of the officials and their lack of accountability. The comments of the tax agents with respect to the knowledge, capability and professionalism of the tax officers were as follows:

'The IRB officer should be more competent so that they can firmly advise taxpayers whether or not a business expenditure is deductible and not always non-deductible. In very rare circumstances, it is deductible, or they don't always commit. They are not even sure but expect the taxpayer to know better than them.'

'It is a known fact that the IRB officers are given a certain collection 'target' to meet as their KPI. Meeting this KPI has caused hardship to taxpayers as officers are interested in their own KPI rather than understanding the real business practices and not arbitrarily deciding against the taxpayer's explanation.'

They argued for tax related expenses to be allowed for tax deduction since this amount is incurred to comply with the segment of the law.

'The government does not grant deduction for tax compliance cost. However, in many developed countries this is a deductible expense. Previously this was a deductible expense until the IRB issued a ruling to disallow such deductions. This is an action that is difficult for the taxpayers to accept. The taxpayers view that if no one generates income, then the question of tax does not arise. This is an example of conflict of interpretation between the taxpayers and the tax authority. Furthermore, taxpayers see that the tax professional tax fees earned by the tax practitioners are being taxed by the government and that they also have to pay service tax to the government. Based on this the taxpayer may feel that they are unfairly burdened by the tax compliance cost.'

Other issues that received numerous comments included ensuring timely and consistent responses to queries; incentives to taxpayers for prompt payment and submission, waiver of company responsibility on employees monthly tax deduction work, removing incentives and lower tax rates across the board, and improving the information made available to the public, such as the IRB website. 


\section{Conclusion}

This paper exhibits the qualitative issues pertaining to tax compliance costs in the context of corporate income tax. With respect to the research findings, this study makes several contributions to the body of knowledge, especially when one takes into consideration the very limited tax studies in the emerging economies. Specifically, the findings in this study enhance the current literature on tax compliance costs with regards to qualitative findings.

Practically, the qualitative findings arising from this study provide valuable information for policymakers in the area of taxation, as well as to the taxation profession and management of companies. Specifically, the findings of this study may provide some direction in refining the overall operations of the tax system that are relevant to the Malaysian Government, in general, and the IRB, in particular. The measures taken in relation to the simplification of the tax system are expected to ease the burden in terms of the compliance costs of corporations. These directions may also be relevant for other countries and in connection with other types of tax.

Based on the qualitative analysis of the findings, the following measures are laid out from the perspective of lowering the compliance burden of corporate taxpayers through improvements to the tax system.

i. Enhancing education and training programmes for taxpayers is worth considering. The tax agents called for more competent and accountable tax officers in terms of their capabilities and professionalism.

ii More clarity concerning the tax legislation and transparency pertaining to the implementation of tax laws were also suggested. Among others, the tax agents pointed out the lack of accountability and transparency in tax administration matters and the ambiguous terminology of the tax legislation.

iii. The tax agents also suggested the need to align tax with the accounting rules. The convergence of the tax law with the accounting standards and practices would reduce discrepancies and tax adjustments, which, in turn, would significantly reduce the compliance burden of the taxpayers.

As a piece of research, this study is not without its limitations and presents opportunities for future research. A limited quantity of data was used in the analysis with only 49 tax agents responding to this study. Thus, the findings of this survey are considered to be tentative. Nevertheless, the responses received from this limited number of respondents are considerable and very informative.

Given the findings and limitations of this study, there are several avenues for future research. This study utilised an open-ended questionnaire based on a researcher-administered survey of the responses of tax agents. Future research should consider conducting in-depth interviews and/or experiments with these tax agents. Research utilising these approaches can be a good complement to 
surveys as they are useful for providing a deeper understanding and explanation concerning the research issues. The use of case studies may provide better quality responses to some issues of interests, including investigation of the measures to reduce the tax compliance burden. It would also be valuable to obtain the views of other stakeholders, especially those of the tax authority, about the various aspects of the tax compliance burden addressed in this study.

\section{References}

Abdul-Jabbar, H. (2009). Income tax non-compliance of small and medium enterprises in Malaysia: Determinants and tax compliance costs. Unpublished doctoral dissertation, Curtin University of Technology, Perth, Australia.

Ariff, M. \& Pope, J. (2002). Taxation and compliance cost in Asia Pacific economies. Sintok: University Utara Malaysia Press.

Arthur D. Little Inc. (1988). Development of methodology for estimating the taxpayer paperwork burden (Final Report to the Department of Treasury). Washington DC: Internal Revenue Service.

Bertolucci, A. (2002). The compliance costs of taxation in Brazil: A survey of costs in Brazilian public companies'. Unpublished doctoral dissertation, University of Sao Paulo, Brazil.

Blazic, H. (2004). Tax compliance costs of companies in Croatia. Ekonomickỳ časopis, 6, 723-38.

Chan, S.Y.S., Cheung, D.K.C., Ariff, M. \& Loh A.L.C. (1999). Compliance Costs of Corporate Taxation in Hong Kong. The International Tax Journal, 24(4), 42-68.

Chattopadhyay, S. \& Das-Gupta, A. (2002). The Income Tax Compliance Costs of Indian Corporations. New Delhi: National Institute of Public Finance and Policy (NIPFP).

Erard, B. (1997). The income tax compliance burden on Canadian big business (Working Paper 97-2). Ottawa, Canada: Technical Committee on Business taxation, Department of Finance.

Evans, C. (2003a). Studying the studies: An overview of recent research into taxation operating costs. eJournal of Tax Research, 1(1), 64-92.

Evans, C., Ritchie, K., Tran-Nam, B. \& Walpole, M. (1996). A report into the incremental costs of taxpayer compliance. Canberra: Australian Government Publishing Service.

Evans, C., Ritchie, K., Tran-Nam, B. \& Walpole, M. (1997). A report into taxpayer costs of compliance. Canberra: Australian Government Publishing Service.

Godwin, M.R. \& Sandford, C. (1983). Simplifying VAT for small traders. Accounting and Business Research, 13(52), 279-288.

Hanefah, M., Ariff, M. \& Kasipillai, J. (2001). Compliance costs of small and medium enterprises. Journal of Australian Taxation, 4 (1), 73-97. 
Klun, M. (2004). Taxation compliance costs for companies in Slovenia. Economic and Business Review for Central and South-Eastern Europe, 6(4), 325-336.

Loh, A., Ariff, M., Ismail, Z., Shamsher, M. \& Ali, M. (1997). Compliance costs of corporate income taxation in Malaysia. Pacific Accounting Review, 9(1), 27-42.

Musgrave, R.A., Musgrave, P.B. \& Bird, R.M. (1987). Public finance in theory and practice ( $1^{\text {st }}$ Canadian ed.). Toronto: McGraw-Hill Ryerson.

Ott, K. \& Bajo, A. (2000). Compliance costs in transitional economies: the Croatian experience. Paper presented at Compliance Costs Symposium, Sydney. Cited in Klun (2004).

Pope, J. (1992). The compliance costs of taxation in australia: An economic and policy perspective (School of Economics and Finance, Working Paper No. 92.07). Perth, Australia: Curtin University.

Pope, J. (1993a). The compliance costs of major Commonwealth taxes in Australia. Unpublished doctoral dissertation, Curtin University of Technology, Perth, Australia.

Pope, J., Fayle, R. \& Chen, D.L. (1991). The compliance costs of public companies' income taxation in Australia, 1986/87 (Research Study No. 13). Sydney, Australia: Australian Tax Research Foundation.

Sandford, C. (1973). Hidden cost of taxation. London: Institute for Fiscal Studies. Sandford, C. (1990). Accountants and the costs of compliance. Accountancy, 104-105.

Sandford, C. (1995a). The rise and rise of tax compliance costs. In C. Sandford (Ed.), Tax compliance costs measurement and policy. The Institute for Fiscal Studies, Bath, UK: Fiscal Publications.

Sandford, C. (1995b). Improving the methodologies. In C. Sandford (Ed.), Tax compliance costs measurement and policy. The Institute for Fiscal Studies, Bath, UK: Fiscal Publications.

Sandford, C., Godwin, M. \& Hardwick, P. (1989). Administration and compliance costs of taxation. Bath, UK: Fiscal Publications.

Sandford, C., Godwin, M., Hardwick, P. \& Butterworth, M. (1981). Costs and benefits of VAT. London: Heinemann.

Sandford, C. \& Hasseldine, J. (1992). The compliance costs of business taxes in New Zealand. Wellington [N.Z.]: Institute of Policy Studies.

Slemrod, J. \& Blumenthal, M. (1996). The income tax compliance of big business. Public Finance Review, 24(4), 41-438.

Slemrod, J. \& Sorum, N. (1984). The compliance cost of the U.S. individual tax system. National Tax Journal, 37, 461-74.

Slemrod, J. \& Venkatesh, V. (2002). The income tax compliance cost of large and mid-size businesses (A report to the IRS LMSB Division). University of Michigan Business School: Office of Tax Policy Research.

Smith, A. (1776). The wealth of nations. In 1999 edition with an introduction and notes by Andrew Skinner, Penguin books, London, New York. 
Steve, S. (2001). An overview of content analysis. Practical assessment, research and evaluation, 7(17). Retrieved from http://PAREonline.net/getvn. asp? $\mathrm{v}=7$ andn $=17$

Tran-Nam, B. (2001). Use and misuse of tax compliance costs in evaluating the GST. The Australian Economic Review, 34(3), 279-90.

Vaillancourt, F. \& Clemens, J. (2008). Compliance and administrative costs of taxation in Canada. In J. Clemens (Ed.), The impact and costs of taxation in Canada: The case for flat tax reform (pp. 55-102). Canada: The Fraser Institute.

Weber, R.P. (1990). Basic content analysis ( $2^{\text {nd }}$ ed.). Newbury Park, California: Sage Publications.

Yesegat, W.A. (2009). Value added tax in Ethiopia: A study of operating costs and compliance. Unpublished doctoral dissertation, ATAX, University of New South Wales, Sydney, Australia. 